\title{
Effect of Shear Wall Location On Seismic Performance of High Raised Buildings
}

\author{
Gajagantarao Sai Kumar ${ }^{1 *}$, Purushotham Rao ${ }^{2}$, Partheepan Ganesan ${ }^{3}$ \\ ${ }^{1,2,3}$ Department of Civil Engineering, MVGR College of Engineering, Visakhapatnam, India
}

\begin{abstract}
Multi-storey buildings tend to get damaged mainly during earthquake. Seismic analysis is a tool for the estimation of structural response in the process of designing earthquake resistant structures and/or retrofitting vulnerable existing structures. The principle purpose of this work is to analyze and design a building with a shear wall and also to find the appropriate position of shear wall that result in maximum resistance towards lateral forces and minimum displacement of the structure. In this study, a G+7 multi-storey building of $15 \mathrm{~m} \times 20 \mathrm{~m}$ in plan area has been chosen and modelled using ETABS. The developed model was validated by solving manually and the results were validated in ETABS. Thereafter, 4 different new plans were modelled in ETABS located in the same earthquake zone area. These plans have shear wall concepts are implemented on the building at four different locations. Seismic, vibration and response spectrum analysis were performed on these structures. Salient parameters such as storey stiffness, storey displacement and storey drift were computed using the ETABS model. These were compared with that of the frame having no shear walls. By comparing the results obtained at different shear wall locations, the best plan with the shear wall having minimum lateral storey displacement and maximum stiffness is suggested for this location.
\end{abstract}

Keywords: ETABS, Shear wall, Seismic analysis, Response spectrum analysis.

\section{Introduction}

Generally, ground motions occur in a random manner in all directions radiating from hypo center during an earthquake event. These random ground motions can cause structures to vibrate and induces inertial forces in them. If these structures are not designed to resist these additional forces it may fail leading to loss of life and property. Thus, the effects of lateral loads such as earthquake forces, wind loads and blast forces, etc. on the structures are attaining increasing importance. There are many techniques to increase the resistance to lateral load of the structure namely, braced moment resisting frames, frameshear wall systems, framed tubular system, etc. The aim of present work is to study effect of the location of shear wall on lateral capacity resisting of the structure.

Chandurkar [2] did a detailed study to determine the solution for shear wall location in multi-storey building with the help of four different models. The buildings were modeled using software ETABS Nonlinear v 9.5.0. After analyzing ten storey building for earthquake located in zone II, zone III, zone IV and zone $\mathrm{V}$ essential parameters like lateral displacement, story drift and total cost required for ground floor were found in both the cases by replacing column with shear wall and conclusion was drawn that shear wall in short span at corner (model 4) is economical as compared with other models. It was observed that shear wall is economical and effective in high rise buildings and providing shear walls at adequate locations substantially reduces the displacement due to earthquake. If the dimensions of shear wall are large then major amount of horizontal forces are taken by shear wall. Varsha R. Harne [3] analyzed a six storey building subjected to earthquake loading in zone II using STAAD Pro and calculated earthquake load using seismic coefficient method (IS 1893 Part II). Four different cases namely a structure without shear wall, structure with $L$ type shear wall, structure with shear wall along periphery and structure with cross type shear wall were analyzed. The lateral deflection of column for building with shear wall along periphery is reduced as compared to other types of shear walls. It was found that shear wall along periphery is most efficient among all the shear walls considered. Similarly, host of other researchers Kameswari et al. (4), Anshuman et al (5), Quahog ZHAO et al (6), Shahabodin. Zaregairizi (7), Men Jinje et al. (8) and Karnale et al. (9) have studied the multi storey building with different shear wall configuration.

In the present work, initially, $15 \mathrm{~m} \times 20 \mathrm{~m}$ size floor plan is taken [1]. Using this as a reference model (model 1), earthquake analysis and response spectrum analysis were done. Base shear, lateral forces are calculated manually and validated with ETABS results, based on this new plan (model 2) is prepared.

\section{Modelling in ETABS}

\section{A. Description of the Model 1}

An eight-storey residential RC building is to be constructed in seismic Zone IV having hard soil. The dimension of the building in planis $15 \mathrm{~m} \times 20 \mathrm{~m}$ with storey height of $3.6 \mathrm{~m}$. Using both seismic coefficient and response spectrum approach base shear was calculated. The inter-storey lateral stiffness of floor is taken as $\mathrm{k} 1=\mathrm{k} 2=\mathrm{k} 3=\mathrm{k} 4=671.52 \times 10^{6} \mathrm{~N} / \mathrm{m}$ and $\mathrm{k} 5=\mathrm{k} 6=$ $\mathrm{k} 7=\mathrm{k} 8=335.76 \times 10^{6} \mathrm{~N} / \mathrm{m}$. Adead load of $5 \mathrm{kN} / \mathrm{m}^{2}$ and live load of $1.5 \mathrm{kN} / \mathrm{m}^{2}$ is considered for roof slab and for floor slab dead load considered was $10 \mathrm{kN} / \mathrm{m}^{2}$ and live load is taken as $4 \mathrm{kN} / \mathrm{m}^{2}$. 


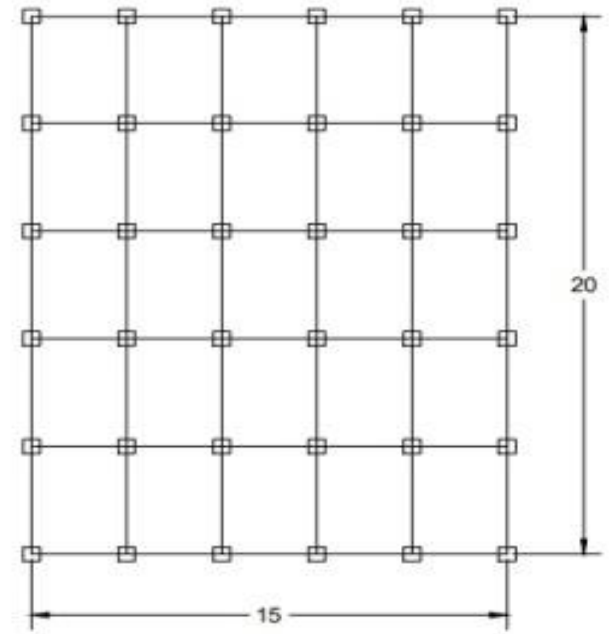

Fig. 1. Structural plan of G+7 storey building of model 1

Table 1

Material Properties

\begin{tabular}{|l|l|}
\hline Grade of Concrete & M30 \\
\hline Grade of Steel & Fe415 \\
\hline Young's modulus of M30 Grade Concrete & $30 \times 10^{6} \mathrm{kN} / \mathrm{m}^{2}$ \\
\hline Density of Reinforced Concrete & $25 \mathrm{kN} / \mathrm{m}^{3}$ \\
\hline
\end{tabular}

\section{B. Description of the Model 2}
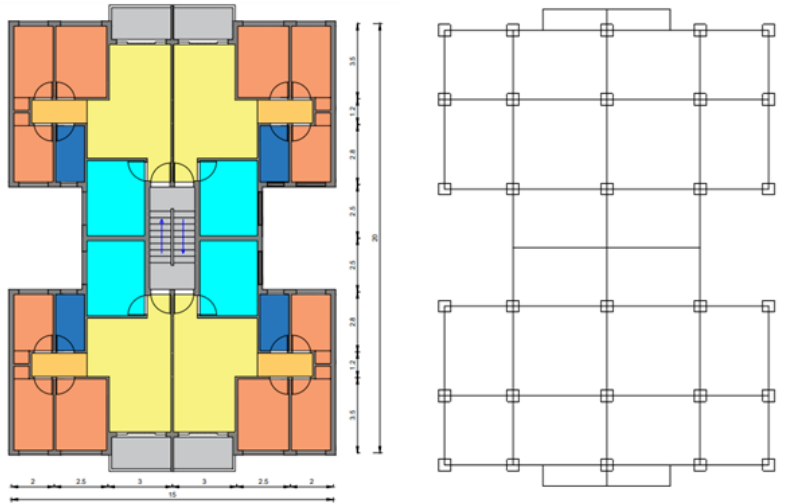

Fig. 2. Plan of G+7 storey building of model 2

\section{Estimation of Base Shear in model 1}

Column size $-0.53 \times 0.53 \mathrm{~m}$

Beam size $-0.30 \times 0.40 \mathrm{~m}$

Slab thickness $-0.12 \mathrm{~m}$.

Zone factor, $Z=0.24$ (Table 2 IS 1893 (part 1): 2002)

Importance factor, I=1.0 (Table 6 IS 1893 (part 1): 2002)

Response reduction factor, $\mathrm{R}=3$ (Table 7 IS 1893 (part 1): 2002)

Seismic weight of building (Clause 7.3.1 IS 1893 (part 1): 2002)
Seismic weight of roof $=15 \times 20 \times 5=1500 \mathrm{kN}$

Seismic weight of each floor $=$ dead load + a fraction of imposed load

$=15 \times 20 \times 10+0.5 \times(15 \times 20 \times 4)=3600 \mathrm{kN}$

Total seismic weight of building,

$\mathrm{W}=1500+7 \times 3600=26700 \mathrm{kN}$

Fundamental natural time period,

$\mathrm{T}_{\mathrm{a}}=0.075 \mathrm{~h} 0.75=0.075 \times(3.6 \times 8) 0.75=0.9324 \mathrm{sec}$.

Spectral acceleration, $\mathrm{Sa} / \mathrm{g}=1 / \mathrm{T}_{\mathrm{a}}=1 / 0.9324=1.0725$.

Design horizontal seismic coefficient,

$$
\begin{gathered}
\mathrm{A}_{\mathrm{h}}=\mathrm{ZIS} / 2 \mathrm{Rg} \\
=0.0429 .
\end{gathered}
$$

Total base shear is $\mathrm{V}_{\mathrm{b}}=\mathrm{A}_{\mathrm{h}} \times \mathrm{W}=0.0429 \times 26700=1145.42 \mathrm{kN}$.

Once the base shear calculation is completed, lateral force for individual storey is calculated from the formulas shown in the table 2.

From the table 2, the lateral forces will increase from bottom of the storey till storey number 7 and it was dropped at roof level. The base shear is continuously increases from roof to base of the building.

\section{Effect of shear wall at location 1:}

At shear wall location 1, the shear wall is placed at all the corners of the building as shown in figure 3 and further analysis is performed for earthquake and response spectrum analysis.

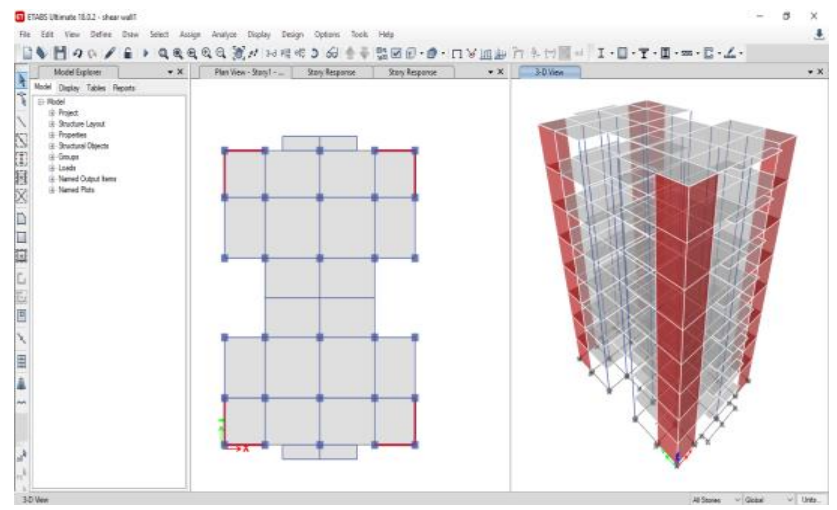

Fig. 3. Geometry model of building with shear wall location 1

At shear wall location 2, the shear wall is placed at middle of the building as shown in figure 4 . Shear wall thickness is considered at $100 \mathrm{~mm}$.

At shear wall location 3, the shear wall is placed at $\mathrm{C}$ type portion at the middle of the building. It is shown in the red color in the following shown in figure 5.

Table 2

Lateral force for individual storey

\begin{tabular}{|l|l|l|l|l|l|}
\hline Floor/Roof & $\mathbf{h}_{\mathbf{i}}(\mathbf{m})$ & $\mathbf{W}_{\mathbf{i}}(\mathbf{k N})$ & $\mathbf{W}_{\mathbf{i} . \mathbf{h}_{\mathbf{i}}{ }^{2} / \mathbf{\Sigma} \mathbf{W}_{\mathbf{i} . \mathbf{h}_{\mathbf{i}}}{ }^{2}}$ & $\mathbf{Q}_{\mathbf{i}}(\mathbf{k N})$ & Base Shear $(\mathbf{k N})$ \\
\hline Roof & 28.8 & 1500 & 0.16 & 183.27 & 183.27 \\
\hline 7 & 25.2 & 3600 & 0.294 & 336.75 & 520.02 \\
\hline 6 & 21.6 & 3600 & 0.216 & 247.41 & 767.43 \\
\hline 5 & 18 & 3600 & 0.15 & 171.81 & 939.25 \\
\hline 4 & 14.4 & 3600 & 0.096 & 109.96 & 1049.21 \\
\hline 3 & 10.8 & 3600 & 0.054 & 61.85 & 1111.06 \\
\hline 2 & 7.2 & 3600 & 0.024 & 27.49 & 1138.55 \\
\hline 1 & 3.6 & 3600 & 0.006 & 6.87 & 1145.42 \\
\hline
\end{tabular}




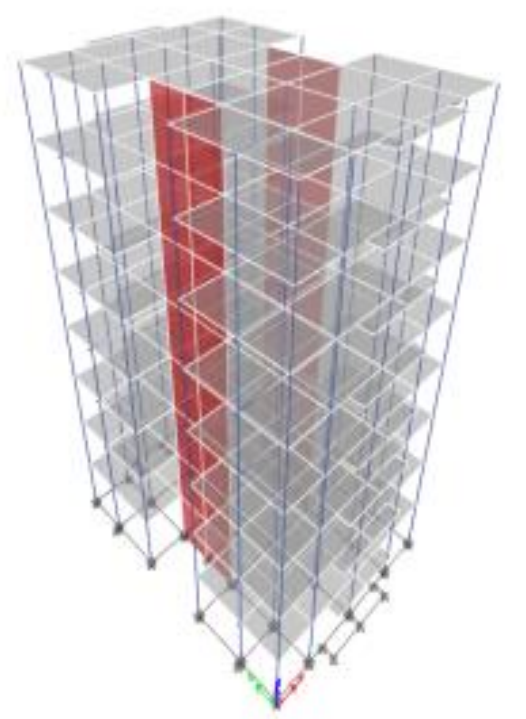

Fig. 4. Geometry model of building with shear wall location 2

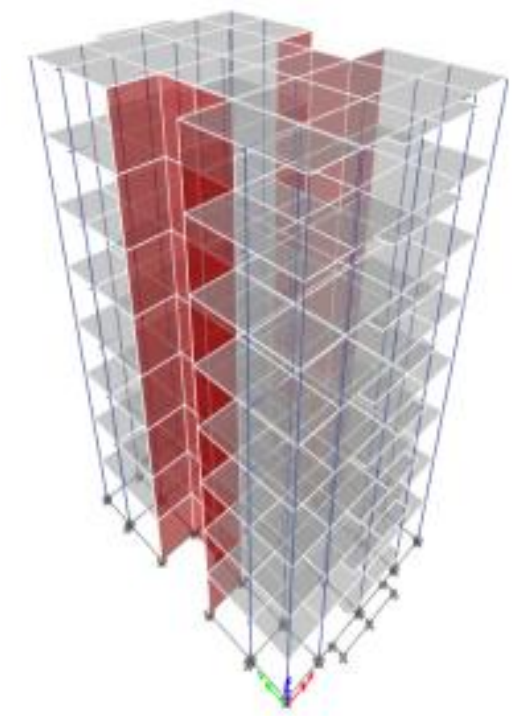

Fig. 5. Geometry model of building with shear wall location 3

At shear wall location 4, the shear wall is placed at the L-type portion at the middle of the building as shown in figure 6 .

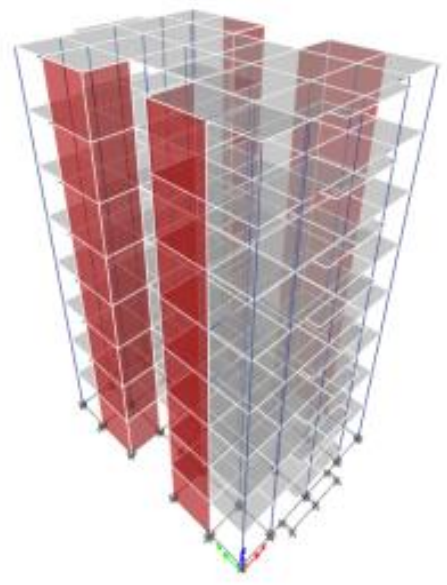

Fig. 6. Geometry model of building with shear wall location 4
Using all 6 models base shear, lateral force, storey displacement, storey drift and storey stiffness are calculated and plotted in the below graph.

The objective of this project is to check and design of the seismic response of multi-storied building using ETABS. For all frame model results are noted from ETABS software.

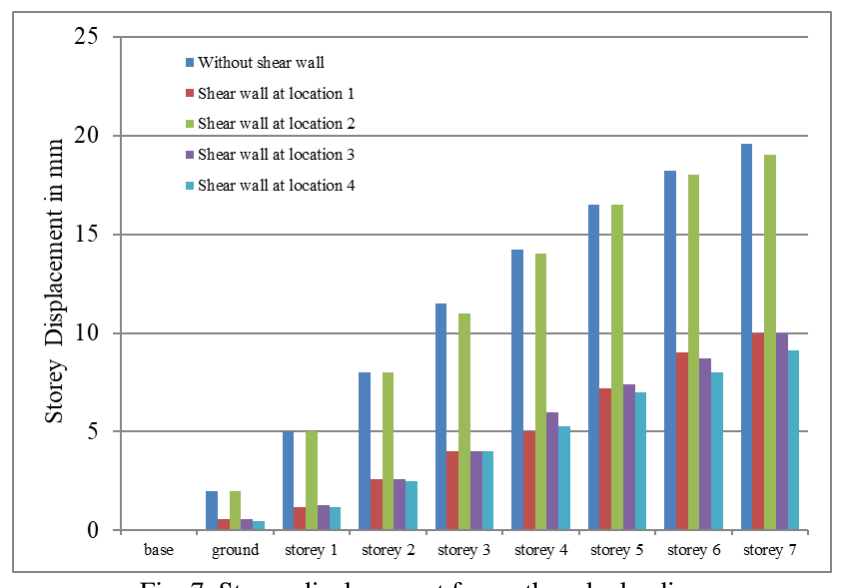

Fig. 7. Storey displacement for earthquake loading

The above figure 7 represents the storey displacement due to Earthquake analysis. The $\mathrm{X}$ axis represents storey number and $\mathrm{Y}$ axis represents the storey displacement in $\mathrm{mm}$. The color line indicates the location of shear wall. The maximum storey displacement was observed for the shear wall placed at location 2.

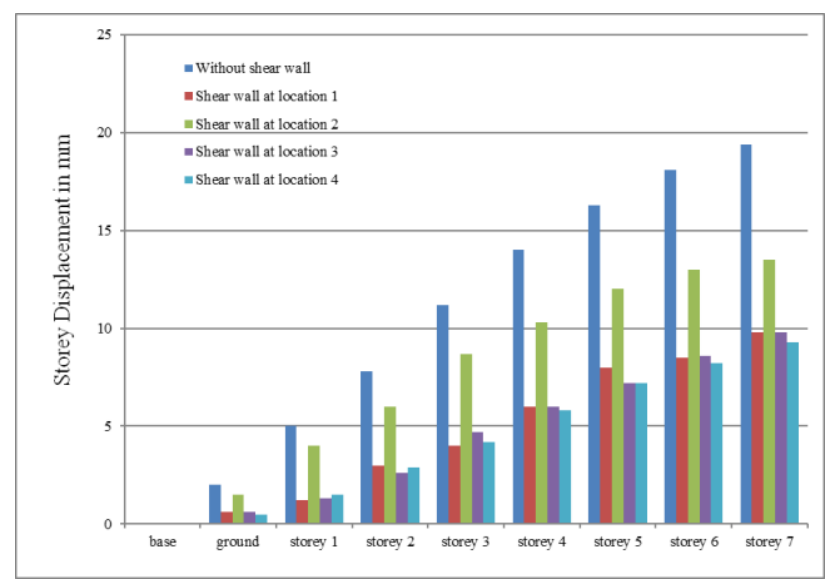

Fig. 8. Storey displacement for response spectrum loading

The above graph represents the storey displacement due to response spectrum analysis. The $\mathrm{x}$-axis represents storey number and $\mathrm{y}$-axis represents the storey displacement in $\mathrm{mm}$. The color line indicates the location of shear wall. At location 2, maximum storey displacement is observed.

The graph (Fig. 9) represents the storey Stiffness due to Earthquake analysis. The $\mathrm{X}$-axis represents storey number and $\mathrm{y}$-axis represents the Storey stiffness $\mathrm{kN} / \mathrm{m}$. The color line indicates the location of shear wall. At location 1, maximum storey stiffness is observed. 


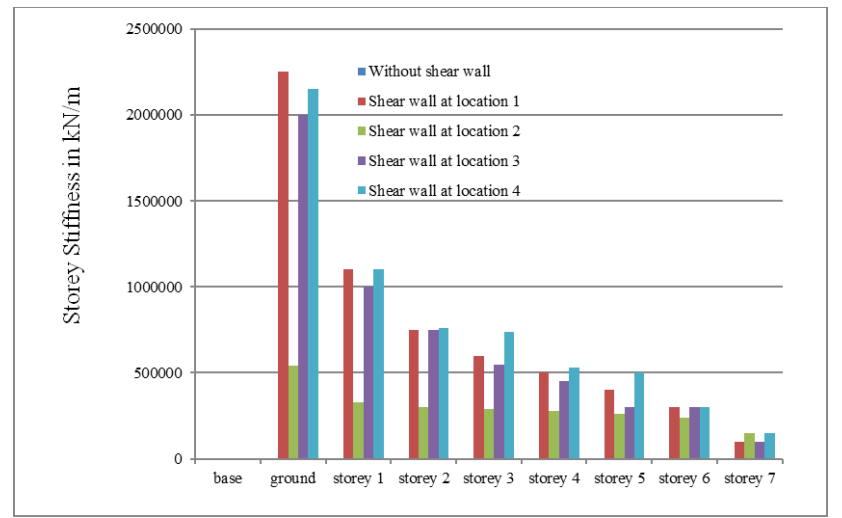

Fig. 9. Storey stiffness of G+7 building

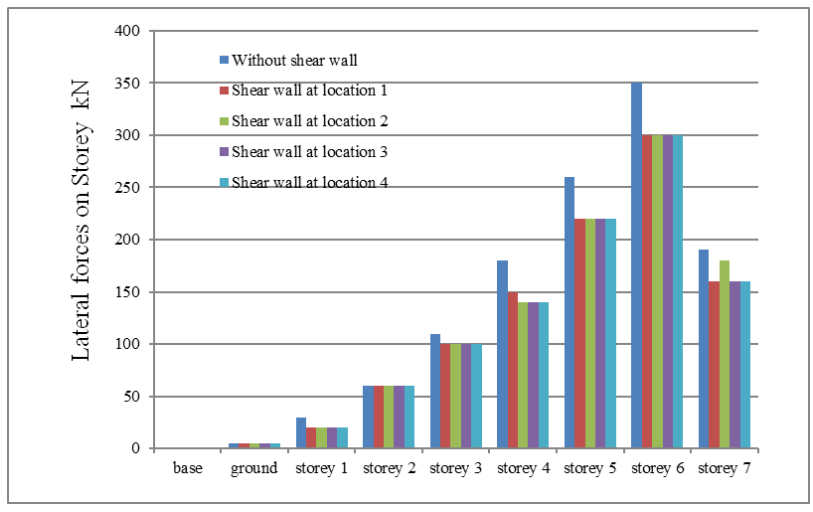

Fig. 10. Lateral forces on storey for earthquake loading

The graph (Fig. 10) represents the storey lateral forces due to Earthquake analysis. The $\mathrm{x}$ axis represents storey number and $\mathrm{Y}$ axis represents the lateral forces in $\mathrm{kN}$. The color line indicates the location of shear wall. Maxim lateral forces are acting on frame model.

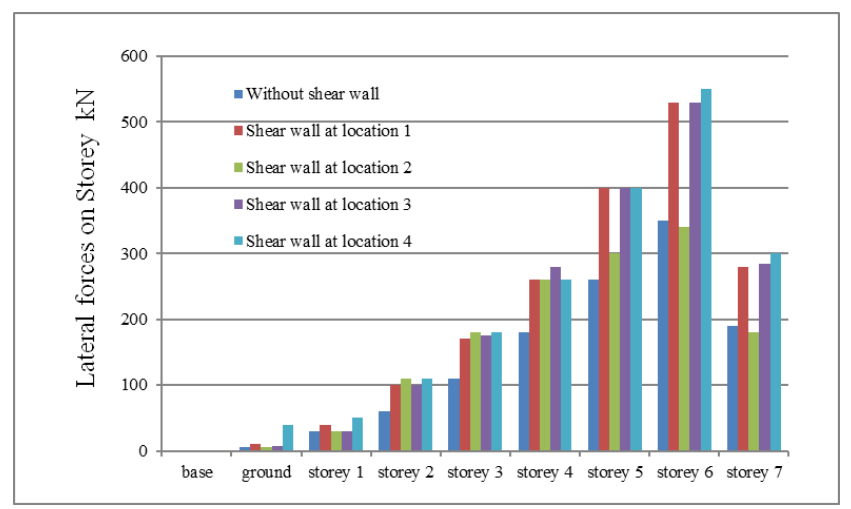

Fig. 11. Lateral forces on storey for response spectrum loading

The graph (Fig. 11) represents the storey lateral forces due to response spectrum analysis. The $\mathrm{x}$-axis represents storey number and $\mathrm{y}$-axis represents the lateral forces in $\mathrm{kN}$. The color line indicates the location of shear wall.

The graph (Fig. 12) represents the storey drift due to earthquake analysis. The $\mathrm{x}$ axis represents storey number and $\mathrm{Y}$ axis represents storey drift (unit less). The color line indicates the location of shear wall.

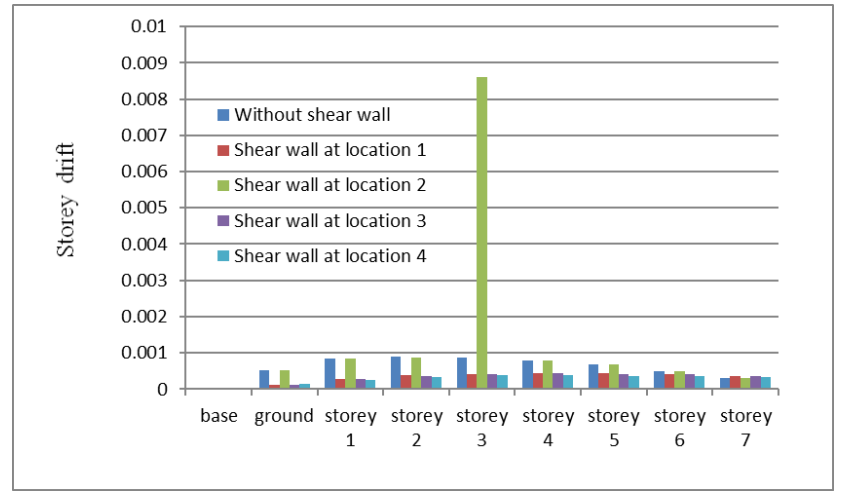

Fig. 12. Storey drift for earthquake loading

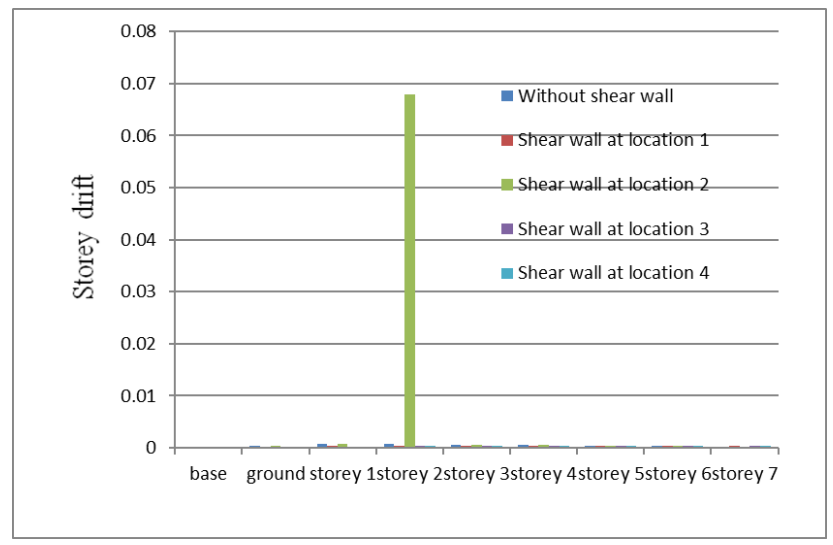

Fig. 13. Storey drift for response spectrum loading

The graph (Fig. 13) represents the storey drift due to response spectrum analysis. The $\mathrm{x}$-axis represents storey number and $\mathrm{y}$ axis represents storey drift (unit less). The color line indicates the location of shear wall.

\section{Conclusion}

In this paper, a $15 \times 20 \mathrm{~m}$ plan area building with $\mathrm{G}+7$ is considered. It was solved and the results are validated, using this methodology a new plan was implemented in same area, as well shear wall concepts are implemented on the building at different locations. By conducting the software analysis for the structures following conclusions are drawn:

1. The displacement is decreased in shear wall structure as compared to framed structure. There is nearly $50 \%$ reduction in displacement of structure is obtained when the shear wall is placed at locations $1,3 \& 4$ in both Earthquake loading and Response spectrum loading cases.

2. Whereas is no significant reduction in displacement of structure occurred when shear wall is placed at location 2 during application of Earthquake loading and there is $31 \%$ of reduction in displacement of structure occurred when shear wall is placed at location 2 during application of response spectrum loading.

3. The story stiffness is increased in greater amount in structure with shear wallwhen compared with frame with no shear walls. The story drift is decreased in shear wall structure than the frame structure. The drift value decreased by $19 \%$ in during earth quake loading and $44 \%$ 
during response spectrum loading.

4. The modal period and Earthquake frequency is less in no shear wall frame structure \& more in shear wall structure.

5. The performance of shear structure is better than the framed structure. Different locations of shear wall is considered and compared to obtain best suitable location of the shear wall. At location 1 we have minimum lateral storey displacement is observed and we have maximum stiffness at this position.

6. The base shear is observed as $1020.7 \mathrm{kN}$ which results in $11 \%$ reduction when compared to framed structure. The cost of the frame structure may be less than the shear structure. The shear structure is suitable in earthquake prone area due to its higher stiffness \& less displacement.

\section{References}

[1] https://nptel.ac.in/content/storage2/courses/105101004/downloads/04\%2 0Chapter.pdf

[2] P. P. Chandurkar, and P. S. Pajgade, "Seismic analysis of RCC building with and without shear wall," in IJMER, vol. 3, no. 3, pp. 1805-1810, May-June 2013.
[3] V. R. Harne, "Comparative study of strength of RC Shear wall at different location on multistoried Residential building", in International Journal of Civil Engineering Research, vol. 5, no. 4, pp. 391-400, 2014.

[4] B. Kameswari, G. Elangovan, P. Sivabala, and G. Vaisakh, "Dynamic Response of High rise Structures under the Influence of discrete staggered shear wall", in IJEST, vol. 3, no. 10, pp. 7789-7798, October 2011.

[5] S. Anshuman, D. Bhunia, and B. Ramjiyani, "Solution of shear wall location in multistory building", in International Journal of Civil and Structural Engineering, vol. 2, no. 2, 2011.

[6] Q. Zhao and A. Astaneh, "Cyclic Behaviour of traditional and innovative composite shear walls," 13th World Conference on Earthquake Engineering.

[7] S. Zaregairizi, "Comparative investigation on using shear wall and infill to improve seismic performance of existing buildings", 14th World Conference on Earthquake Engineering.

[8] M. Jinjie, S. Qingxuan, and H. Zhijian, "Optimal Design of Tall Residential Building with Shear wall and with Rectangular layout," in International Journal of High Rise Buildings, vol. 3, no. 4, pp. 285-296, December 2014.

[9] A. B. Karnale and D. N. Shinde, "Comparative Seismic Analysis of High Rise and Low Rise RCC Building with Shear Wall," in International Journal of Innovative Research in Science, Engineering and Technology, September 2015. 